\title{
Genito-Urinary Function and Quality of Life after Elective Totally Laparoscopic Sigmoidectomy after at Least One Episode of Complicated Diverticular Disease According to Two Different Vascular Approaches: the IMA Low Ligation or the IMA Preservation. A Prospective Multicenter Parallel Study
}

\author{
Giulio Mari', Jacopo Crippa', Andrea Costanzi', Michele Mazzola², Carmelo Magistro², Giovanni Ferrari² and Dario Maggioni'
}

${ }^{1}$ General Surgery Department, Desio Hospital, Desio (MB) Italy

${ }^{2}$ General Surgery Department, Niguarda Hospital, Milan (MI) Italy

Corresponding author:

Mari Giulio, MD

ASST Monza, Desio Hospital via Mazzini 3 Desio, Lombardia italy

E-mail: giul_mari@yahoo.it
Abbreviations:

GIQLI: Gastro-intestinal Quality

of Life Indicator;

GUF: genito-urinary function;

ICIQ-UI: Iciq-urinary incontinence;

IMA: inferior mesenteric artery;

IP: IMA preservation

LCA: left colic artery;

LL: Low Ligation

QOL: Quality of Life

Received: 27.03.2017

Accepted: 15.04.2017

\section{Rezumat}

Functia genito-urinară și calitatea vietii după sigmoidectomie totală laparoscopică de electie după cel puțin un episod de diverticulită complicată în functie de două abordări vasculare diferite: ligaturarea joasă a arterei mezenterice inferioare sau prezervarea acesteia. Un studiu prospectiv multicentric paralel

Ligaturarea arterială în timpul sigmoidectomiei laparoscopice de elecție pentru boală diverticulară poate afecta funcția genitourinară, lezând plexul hipogastric superior, şi poate diminua perfuzia arterială la nivelul bontului colonic distal. Ligaturarea arterei mezenterice inferioare distal de artera colică stângă sau prezervarea completă a arterei mezenterice inferioare pot fi comparate prin urmare din perspectiva prezervării fibrelor simpatice descendente cu traiect de-a lungul aortei şi către rect, rezultând în funcții genito-urinare postoperatorii diferite. În perioada ianuarie 2015-martie 2016, 66 de pacienți au fost supuşi sigmoidectomiei laparoscopice de elecție pentru boală diverticulară, în cadrul a 2 spitale participante la studiu. Într-unul dintre centre, 35 de pacienți au fost supuşi sigmoidectomiei laparoscopice cu ligaturarea arterei mezenterice inferioare distal de artera colică stângă (ligaturare joasă). În celălalt centru, 31 de pacienți au fost operați utilizând aceeaşi procedură, de această dată cu prezervarea arterei mezenterice inferioare. $\mathrm{Nu}$ au existat diferențe între cele 2 grupuri în ceea ce priveşte complicațiile majore apărute, primul scaun postoperator sau durata spitalizării. Durata operației a fost semnificativ mai scurtă în grupul de ligaturare joasă comparativ cu 
grupul de prezervare a AMI, iar volumul de sângerare intraoperatorie a fost semnificativ mai scăzut în grupul de ligaturare joasă. $\mathrm{Nu}$ au existat diferențe între cele două grupuri în ceea ce priveşte funcția genito-urinară preoperator, la o lună şi la 9 luni postoperator. Funcția genito-urinară nu s-a modificat semnificativ pe parcursul operației în nici unul dintre cele două grupuri. Abordările vasculare de ligaturare joasă şi prezervare a AMI sunt tehnici fezabile cu rezultate sigure în sigmoidectomia laparoscopică de elecțiepentru boală diverticulară. Ambele previn disfuncția genitourinară postoperatorie şi asigură o calitate a vieții bună postoperator. Abordarea ligaturării joase se asociază cu un timp operator mai scăzut şi sângerare introperatorie încetinită.

Cuvinte cheie: boală diverticulară, sigmoidectomielaparoscopică, prezervarea arterei mezenterice inferioare (AMI), funcție genito-urinară

\begin{abstract}
The arterial ligation during elective laparoscopic sigmoidectomy for diverticular disease can affect genito-urinary function injuring the superior hypogastric plexus, and can weaken the distal colonic stump arterial perfusion. Ligation of the inferior mesenteric artery distal to the left colic artery or the complete preservation of the inferior mesenteric artery can therefore be compared in terms of preservation of the descending sympathetic fibres running along the aorta to the rectum resulting in a different post operative genito urinary function. From January 2015 to March 2016, 66 patients underwent elective laparoscopic sigmoidectomy for diverticular disease among two enrolling hospitals. In one centre 35 patients underwent laparoscopic sigmoidectomy with the ligation of the inferior mesenteric artery distal to the left colic artery (low ligation). In the other centre 31 patient were operated on the same procedure with complete inferior mesenteric artery preservation (IMA preservation). There was no difference in terms of major complication occurred, first passage of stool and length of hospital stay between the two groups. Time of surgery was significantly shorter in LL group compared to IMA preserving group and intra operative blood loss was significantly lower in the LL group. There were no differences in the genito urinary function between the two group pre operatively, at 1 and 9 months post operatively. Genito urinary function did not significantly change across surgery in each groups. The low ligation and the IMA preserving vascular approach are safe end feasible techniques in elective laparoscopic sigmoidectomy for diverticular disease. They both prevent from genito-urinary post-operative disfunction and allow good post operative quality of life. The low ligation approach is related to shorter operative time and slower intra operative blood loss.
\end{abstract}

Key words: diverticular disease, laparoscopic sigmoidectomy, IMA preservation, genito urinary function

\section{Introduction}

The level of the vascular approach in laparoscopic sigmoid resection for diverticular disease still represent a debated issue.

The prevalence of diverticular disease (DD) is reported to be $5 \%$ of people in their forties and as high as $80 \%$ in those aged older than 80 years. Its importance in terms of clinical presentation and treatment costs has been widely inquired (1).

Laparoscopic approach is the treatment of choice for elective surgery in patients with diverticular disease, being associated with lower morbidity than the open approach $(2,3)$.

Indication for elective sigmoid resection has been changing through years.

In 2006 elective surgery was recommended 
after one episode of complicated diverticulitis and a case-to-case approach was proposed after one or more episodes of uncomplicated diverticulitis (4).

What still needs to be clarified is the standardization of such a procedure. The way in which surgery is carried on can in fact deeply affect the immediate postoperative period, the long-term functional outcomes and the recurrence rate.

As Ambrosetti et al. pointed out three technical aspects are mainly important in laparoscopic sigmoid resection for DD: the site of the proximal colonic division, the mobilization of the splenic flexure and the vascular approach. While for the first aspect a general agreement is close to be reached, for the others there is still no consensus up to now (5).

The level of the vascular approach above all is performed differently according to reported series.

Three methods are commonly used. Division of the inferior mesenteric artery (IMA) proximal to the left colic artery (LCA) (high tie), division of the (IMA) distally to the LCA (low tie), preservation of the IMA (6).

The level of arterial ligation can affect genito-urinary function (GUF) injuring the superior hypogastric plexus, and can weaken the distal colonic stump arterial perfusion (7).

The concern for insufficient marginal artery leading to colonic ischaemia suggests that high ligation in laparoscopic sigmoid resection for DD is to much of a risk above all for non oncological patients.

Differences between Low tie and preservation of the IMA can be appreciated in terms of preservation of the descending sympathetic fibres running along the IMA to the rectum resulting in a better post operative GUF (8).

From an anatomical point of view the farer the dissecting plane is from neural structures the safer dissection should be in terms of GUF preservation. However going into the mesum of the sigmoid colon could be uneasy and alter the anatomical perception leading to misunderstanding of the surgical planes.

This study compares the genito urinary function of patients undergoing laparoscopic elective sigmoid resection for diverticular disease according to two different vascular approaches: the low tie of the IMA distally to the LCA and the preservation of the IMA. Aim of this trial is to assess the impact of the level of the arterial ligation on GUF and on quality of life in order to help to standardize the best technical approach in laparoscopic sigmoid resection for DD.

\section{Methods}

This study is a prospective controlled parallel study. Patients were enrolled in two different hospitals. In one centre patients were approached with the low tie technique, in the other patients were approached with the IMA preservation technique.

Inform consent was collected at the time of patients enrolling.

Indication for elective colonic resection was the same in both hospital: at least 1 docu- $^{-}$ mented episode of complicated diverticulitis or a case to case indication tailored on patients' symptoms. For inclusion in the study group all patients had to have a CT of the abdomen and pelvis with an enema at the time of one attack.

Questionnaires for the Internation Index of Erectile Function, International Consultation on Incontinence Questionnaire (10), International Prostatic Symptoms Score, and Female Sexual Function Index (11) were administrated preoperatively and 1 and 9 months postoperatively to all patients. Uroflowmetry and the ultrasound measurement of post-void bladder volume were performed pre-operatively and 1 and 9 months post-operatively.

Intra-operative data such as time of surgery, blood loss, conversion rate, need for diversion, were collected for all patients.

Short term outcomes such as complications, leakage, re-intervention, first passage of flatus and stool, day of discharge were also collected.

QOL was investigated with the Gastrointestinal Quality of Life Indicator (GIQLI) developed to indicate QOL in patients undergoing major gastrointestinal surgery $(12,13)$. GIQLI score was assessed for all patients at 
the admission and at 1 and 9 months postoperatively.

\section{Operative tecnique}

Medial to lateral approach was performed for all patients. The splenic flexure was mobilized only as much as needed to obtain adequate length to perform a tension-free anastomosis. Lateral freeing of the descending colon was always performed. The distal resection was performed with a linear stapler below the colorectal junction. The colorectal anastomosis was performed end-to-end following a Knight \& Griffen. Technique.

In patients for whom IMA was entirely preserved the level of vascular division was taken at the branches of the sigmoid vessels.

In patients who underwent the low ligation vascular approach the rectal artery was divided right distally to the LCA.

\section{Results}

From January 2015 to March 2016, 66 patients underwent elective laparoscopic sigmoidectomy for diverticular disease among the two enrolling hospitals. Patient characteristics in terms of age, body mass index, sex, American Society of Anaesthesiologists classification are described in Table 1.

$100 \%$ of samples were collected and analyzed as scheduled.

35 patients underwent laparoscopic sigmoidectomy with a low ligation vascular approach (LL group), 31 patients with the IMA preservation approach (IP group).

20 patients in LL group and 21 patients in IP groups received the indication for surgery after an episode of complicated diverticulitis treated conservatively. 15 patients in LL group and 10 in IP group received the indication for surgery after after repeated episodes of uncomplicated diverticular disease or after the onset of chronic abdominal symptoms.

There was no difference in terms of major complication occurred, first passage of stool and length of hospital stay between the two groups. Time of surgery was significantly shorter in LL group compared to IP group while intra operative blood loss was significantly higher in LL group Table 2.

No stoma was performed in both groups and there was no laparotomic conversions either.

Table 1. Patient characteristics

\begin{tabular}{|c|c|c|c|c|}
\hline & Tot. & LL & IP & $\mathbf{p}$ \\
\hline$n$ & 66 & 35 & 31 & \\
\hline Male & 36 & 18 & 18 & n.s. \\
\hline Female & 30 & 17 & 13 & n.s. \\
\hline ASA 1 & 15 & 11 & 14 & n.s. \\
\hline ASA 2 & 40 & 23 & 17 & n.s. \\
\hline ASA 3 & 1 & 1 & 0 & n.s. \\
\hline B.M.I. & $26,8( \pm 4.5)$ & $27.3( \pm 4.2)$ & $26.5( \pm 3.8)$ & n.s. \\
\hline Age & $58(24-79)$ & $57(24-78)$ & $60(34-79)$ & n.s. \\
\hline Complicated diverticular disease & 41 & 20 & 21 & n.s. \\
\hline Perforation & 32 & 16 & 16 & n.s. \\
\hline Stenosis & 7 & 3 & 4 & n.s. \\
\hline Bleeding & 2 & 1 & 1 & n.s. \\
\hline Uncomplicated diverticular disease & 25 & 15 & 10 & n.s. \\
\hline 1 episode & 1 & 0 & 1 & n.s. \\
\hline 2 episodes & 18 & 11 & 7 & n.s. \\
\hline$>2$ episodes & 6 & 4 & 2 & n.s. \\
\hline
\end{tabular}

LL: Low Ligation; IP: IMA preservation; ASA: American Society of Anesthesiologists Score; B.M.I: Body Mass Index 
Table 2. Post-operative parameters

\begin{tabular}{|c|c|c|c|}
\hline Parameters & LL (35) & IP (31) & $\mathrm{p}$ \\
\hline Time of surgery (min) & $135 \pm 28$ & $175 \pm 31$ & $p<0,05$ \\
\hline Blood loss (ml) & $55 \pm 16$ & $81 \pm 22$ & $p<0,05$ \\
\hline Postoperative hospital stay & $5 \pm 2,1$ & $6 \pm 2$ & n.s. \\
\hline Major complication & 2 & 3 & n.s. \\
\hline Anastomotic leak & 1 & 2 & n.s. \\
\hline Bleeding & 0 & 1 & n.s. \\
\hline lleus & 1 & 0 & n.s. \\
\hline Re-operation & 2 & 3 & n.s. \\
\hline
\end{tabular}

Table 3. Urinary function

\begin{tabular}{|c|c|c|c|c|c|}
\hline & $n^{\circ}$ & Time & LL & IP & p-value \\
\hline \multirow[t]{3}{*}{ IPSS } & 36 & Pre - op & $7.8 \pm 3$ & $8.1 \pm 2.6$ & ns \\
\hline & 36 & 1 & $8 \pm 3.5$ & $8.9 \pm 4$ & ns \\
\hline & 36 & 9 & $8.1 \pm 3.3$ & $9 \pm 2.6$ & ns \\
\hline \multirow[t]{3}{*}{$\mid \mathrm{CIQ}-\mathrm{UI}$} & 66 & Pre - op & $1 \pm 0.5$ & $1.1 \pm 0.8$ & ns \\
\hline & 66 & 1 & $1.6 \pm 0.9$ & $1.9 \pm 0.6$ & ns \\
\hline & 66 & 9 & $1.1 \pm 0.7$ & $1.7 \pm 0.5$ & ns \\
\hline
\end{tabular}

Comparison of the average value of the questionnaires pre operatively, at 1 month and 9 months: IPSS: International prostatic symptom score; ICIQ-UI: Iciq-urinary incontinence

GIQLI score pre-operatively measured was similar between the two groups (LL $124 \pm 7,4$ vs IP $122 \pm 8,6$ n.s.). There were no differences between groups at 1 and 9 months p.o. (LL 120 $\pm 9,7$ vs IP $121 \pm 10,1$ at one months, n.s.), (LL $123 \pm 6,2$ vs IP $123 \pm 7,7$ at nine months, n.s.). GIQLI score did not significantly change also within each group across surgery.

Urinary function inquired with IPSS and
ICIQ-UI questionnaire did not show significant differences between groups before and after surgery (Table 3).

Uroflowmetric test performed pre operativly, at one and nine months post operatively, did not show significant differences between groups. Surgery did not significantly affect urinary function according to collected data. (Table 4)

Sexual function measured through IIEF

Table 4. Urinary function Urofluwometric Test

\begin{tabular}{|c|c|c|c|c|c|}
\hline & $\mathrm{N}^{\circ}$ & & LL & IP & \\
\hline \multirow[t]{3}{*}{$Q \max (\mathrm{ml} / \mathrm{s})$} & 66 & PRE & $17,9 \pm 4,78$ & $15,8 \pm 3,1$ & ns \\
\hline & 66 & 1 & $16,2 \pm 5,2$ & $16,2 \pm 4,2$ & ns \\
\hline & 66 & 9 & $16,1 \pm 4,0$ & $15,3 \pm 2,7$ & ns \\
\hline \multirow[t]{3}{*}{ Qave $(\mathrm{ml} / \mathrm{s})$} & 66 & PRE & $11,1 \pm 2,9$ & $12,1 \pm 3$ & ns \\
\hline & 66 & 1 & $10,5 \pm 4,1$ & $11,8 \pm 2,9$ & ns \\
\hline & 66 & 9 & $11,3 \pm 4,1$ & $11,7 \pm 2,8$ & ns \\
\hline \multirow[t]{3}{*}{ PVR (ml) } & 66 & PRE & $59,6 \pm 21$ & $49,1 \pm 15,5$ & \\
\hline & 66 & 1 & $64,5 \pm 32,2$ & $49,5 \pm 20,3$ & $\mathrm{~ns}$ \\
\hline & 66 & 9 & $52,8 \pm 19,6$ & $54,8 \pm 12,7$ & ns \\
\hline
\end{tabular}

Qmax: maximum flow, $Q$ ave: average flow, PVR: post-voidal remnant volume 
Table 5. Sexual function

\begin{tabular}{|c|c|c|c|c|c|}
\hline FSFI & $n^{\circ}$ & Time & LL & IP & p-value \\
\hline & $10^{*}$ & Pre - op & $30 \pm 4$ & $29 \pm 6$ & \\
\hline & $10^{*}$ & 1 & $26 \pm 7$ & $28 \pm 4$ & ns \\
\hline & $10^{*}$ & 9 & $30,2 \pm 5$ & $28 \pm 5$ & ns \\
\hline \multirow[t]{3}{*}{ IIEF } & 36 & Pre - op & $20,1 \pm 4.4$ & $21,1 \pm 5,1$ & ns \\
\hline & 36 & 1 & $18,4 \pm 6,0$ & $17,1 \pm 6,2$ & ns \\
\hline & 36 & 9 & $19,2 \pm 4,7$ & $18,3 \pm 4,9$ & ns \\
\hline
\end{tabular}

Comparison of the average value of the questionnaires pre operatively, at 1 month and 9 months: FSFI: Female Sexual Function Index adapted score; IIEF: International Index Erectile Function;

*Only 10/30 women declared to be sexual active.

questionnaire did not show significant differences between groups before and after surgery. Surgery itself did not seem to affect sexual function. A small percentage of enrolled women declared to be sexual active (Table 5).

\section{Discussion}

The ligation of IMA at the origin has never been an indication during laparoscopic left hemicolectomy for diverticular disease. Once the presence of cancer has been excluded the oncological vascular ligation becomes a clear over-treatment. Moreover the threaten of injuring the the sympathic fibers of the superior hypogastric plexus leads to vascular ligations far from the aorta.

Low Ligation of the IMA allows to maintain a significant physical distance from the dissecting plane and the superior hypogastric plexus preserving an adequate blood supply for the colonic stump $(5,7)$. From this point of view the IMA preserving technique could be even safer than the Low Ligation technique. However from data collected there was no significant differences in GU postoperative function between the two groups and the anastomotic leak rate has been similar despite of the different levels of arterial ligation. Both techniques resulted in being adequate in terms of GUF preservation $(6,8)$. Data at nine months post-operatively in fact do not significantly differ from baseline pre operative settings in each group. LL is theoretically more threatening towards GUF preservation, nevertheless a careful dissection in experienced hands seem to provide the same results with shorter operative time.

Time of surgery and blood loss in fact were significantly higher in IP group. IMA preserving needs the creation of a dissecting plane not fully anatomical. The sigmoid vessels in fact have to be dissected in the mesum of the sigmoid colon while in LL the separation of Told plane from Gerota fascia can still be performed. In patients recovered from complicated diverticulitis the mesum of the sigmoid colon can remain thickened due to unresolved inflammation. Sectioning the sigmoid branches could therefore be uneasy increasing the risk of bleeding. On the other hand in patients for whom the indication for sigmoidectomy has been given after uncomplicated diverticulitis IMA preserving could be performed on softer tissues resulting more adequate.

Data about QOL collected pre and post operatively confirm what is already present in literature. Laparoscopic elective procedures for diverticular disease do not impair QOL $(14,15)$.

The $0 \%$ converison rate and the avoidance of stoma creation suggest how elective laparoscopic sigmoidectomy is a feasible and safe procedure in experienced hands (16). 2 cases of anastomotic fistula in the IP group and 1 in the LL group happened after anastomotic bleeding. They all were treated with anastomosis redo and temporary ileostomy.

The main limitation of this study is to be a 
prospective comparative study rather than randomized. However data collected can help in achieving the best standardized technique for laparoscopic sigmoidectomy for diverticular disease adding knowledge to an open and debated surgical issue.

\section{Conclusion}

The low ligation and the IMA preserving vascular approach are safe end feasible techniques in elective laparoscopic sigmoidectomy for diverticular disease. They both prevent from GUF postoperative disfunction and allow good post operative QOL. The low ligation approach is related to shorter operative time and smaller intra operative blood loss. IMA preserving technique could be the treatment of choice in selected patients.

\section{References}

1. Senagore AJ. Laparoscopic sigmoid colectomy for diverticular disease. Surg Clin North Am. 2005;85(1):19-24, vii.

2. Gaertner WB, Kwaan MR, Madoff RD, Willis D, Belzer GE, Rothenberger DA, et al. The evolving role of laparoscopy in colonic diverticular disease: a systematic review. World J Surg. 2013;37(3): 629-38.

3. Gervaz P, Inan I, Perneger T, Schiffer E, Morel P. A prospective, randomized, single-blind comparison of laparoscopic versus open sigmoid colectomy for diverticulitis. Ann Surg. 2010;252(1):3-8.

4. Ambrosetti P, Gervaz P. Management of sigmoid diverticulitis: an update. Updates Surg. 2016;68(1):25-35.

5. Ambrosetti P, Gervaz P. Laparoscopic elective sigmoidectomy for diverticular disease: a plea for standardization of the procedure.
Colorectal Dis. 2014;16(2):90-4.

6. Borchert DH, Schachtebeck M, Schoepe J, Federlein M, Bunse J, Gellert K, et al. Observational study on preservation of the superior rectal artery in sigmoid resection for diverticular disease. Int J Surg. 2015;21:45-50.

7. Cirocchi R, Trastulli S, Farinella E, Desiderio J, Listorti C, Parisi A, et al. Is inferior mesenteric artery ligation during sigmoid colectomy for diverticular disease associated with increased anastomotic leakage? A meta-analysis of randomized and non-randomized clinical trials. Colorectal Dis. 2012;14(9):e521-9.

8. Lehmann RK1, Brounts LR, Johnson EK, Rizzo JA, Steele SR. Does sacrifice of the inferior mesenteric artery or superior rectal artery affect anastomotic leak following sigmoidectomy for diverticulitis? a retrospective review. Am J Surg. 2011;201(5):623-7.

9. Jones LA. The use of validated questionnaires to assess female sexual dysfunction. World J Urol. 2002;20:89 -92.

10. Avery K, Donovan J, Peters TJ, Shaw C, Gotoh M, Abrams P. ICIQ: a brief and robust measure for evaluating the symptoms and impact of urinary incontinence. Neurourol Urodyn. 2004;23(4):322-30.

11. Kieres P, Rokita W, Stanisławska M. The diagnostic value of chosen questionnaires (UDI 6SF, Gaudenz, MESA, ICIQ-SF and King's Health Questionnaire) in diagnosis of different types of women's urinary incontinence. Ginekologia polska. 06/2008; 79(5):338-41.

12. Eypasch E, Williams JI, Wood-Dauphinee S, Ure BM, Schmülling C, Neugebauer E, et al. Gastrointestinal Quality of Life Index: development, validation and application of a new instrument. Br J Surg. 1995;82(2):216-22.

13. Schwenk W, Neudecker J, Haase O, Raue W, Strohm T, Müller JM. Comparison of EORTC quality of life core questionnaire (EORTC-QLQC30) and gastrointestinal quality of life index (GIQLI) in patients undergoing elective colorectal cancer resection. Int J Colorectal Dis. 2004;19(6):554-60. Epub 2004 Jun 16.

14. Forgione A, Leroy J, Cahill RA, Bailey C, Simone M, Mutter D, et al. Prospective evaluation of functional outcome after laparoscopic sigmoid colectomy. Ann Surg. 2009;249(2):218-24.

15. Forgione A, Guraya SY. Elective colonic resection after acute diverticulitis improves quality of life, intestinal symptoms and functional outcome: experts' perspectives and review of literature. Updates Surg. 2016;68(1):53-8.

16. Ambrosetti $P$, Francis $K$, Weintraub D, Weintraub J. Functional results following elective laparoscopic sigmoidectomy after CT-proven diagnosis of acute diverticulitis evaluation of 43 patients and review of the literature. J Gastrointest Surg. 2007;11(6):767-72. 